\title{
Theatrics In Modern Christian Worship In Nigeria
}

\author{
ILAMI KRAMA CLIVE, PhD \\ Media Sociology Lecturer \\ Department of Theatre and Film StudiesUniversity of Port HarcourtNigeria
}

\begin{abstract}
The theatre as an institution is expressive of all relationships and vital in the interaction process of the people. The theatre enhances the adoption and adaptation of processes that make every society stable. A cursory look at the history of the theatre reveals a robust romance between the theatre and all forms of religion. It is a historical fact that the theatre emerged from ceremonies of worship. The focus of this paper is on the various effects and elements of the theatre that are evident on Christian worship as well as the role of these effects on the flow of the worship activities. From the medieval period when the theatre was copiously used to enhance clarity of the church doctrine, the theatre has played a prominent role in shaping the development of the church. The theatre was vital in relaying the strange doctrine of the church to the people. The theatrics used by the orthodox churches added piety, atmosphere and conveyed a mystery presence during worship activities. More so, the paper seeks to examine how the robust theatrics have enhanced the flow of modern church activities in Nigeria. The methodology is exploratory and depended on secondary data. The findings reveal that the theatrics used by the orthodox and Pentecostal churches have created a good rapport of worshippers. More so that the theatrics have enhanced the rapid expansion of the churches in Nigeria and that the churches now run a separate budget for theatrics.
\end{abstract}

Key words: Theatrics, Worship, Christian, Modern, Elements, Rites.

\section{INTRODUCTION}

The theatre as a human construct has implication for human activities. There is hardly a strong definition of what is not theatre in every given situation. In the analysis of human interactions, the theatre has come to play a significant role in the creation of meaning and the understanding of the meaning created. Most people fail to understand that the theatre is implied in all human activities. Perhaps the error is in the limiting of the theatre to imitations of past activities. The theatre is life in progress as the past is linked with the present. The theatre is both presentational and representational. Therefore, the location of the theatre as representational will limit the role of the theatre in human activities. All human actions are learned and conditioned which is the vehicle of the theatre. The theatre is expressive and reflective of all human actions. It is this attribute of the theatre that has made it ubiquitous and essential for interrelationships of both society as well as individuals. The early history of man saw the use of theatrics in conveying experiences and feelings. These were expressed in propitiation dances, ritual dances and hunting dances in anticipation for games. In modern times society has employed more theatrics in sports, marriage ceremonies, street demonstrations, protests, war and worships.The medieval experimentation of incorporating theatrics in the church worship programmes enhanced a robust spread of the church. It is the effective use of theatrics that made possible in assimilating the strange message of the church to the early people. The mystery plays, the miracle plays and the travelling troops encouraged the spread of Christianity.The Pentecostal churches and even the orthodox churches have increased the use of theatrics in worship programmes. Theatre groups are increasingly formed by church organizations which encourage new methods of evangelism as a diversion from traditional preaching. The use of theatrics by modern church organizations embellishes the rapport between the worshippers and the secular society. The theatrics employed in Christian worship progammes in Nigeria has been able to break sect rigidity and doctrinal boundaries. The stress encountered by urban dwellers and in particular during the recession encourage the use of theatrics by the church organization to attract more audience. The theatrics appeal more to the audience who are both members and the non members. The audience looks for the theatrics as a way out of emotional stress; the theatrics appeal and serve as a therapy for the members. A great part of the church worship programmes is devoted to the effects of theatrics and which takes a big size of the church budget.

\section{THEATRE IN RELIGIOUS WORSHIP}

Religion and theatre are cultural universals. Both are constructs that are collective and interactive. Religion and theatre are twin engines that drive human development across the ages. The origin of religion and theatre are difficult to explain but both have remain ubiquitous and vital in the drive for human collectivation. Religious 
practices dovetail into theatrical practice In fact, where theatricals activities stop is where religious activities begin. In fact it will be very difficult for an on looker to determine if a ritual possession is worship or theatrical. The analysis or the assumption here is to explain how inexplicable theatre is from religion. Daniel Ilega explains that:

Responding more and more to the needs of the people, therefore indigenous ways and ideas are being used in evangelism...for instance, local drums, instruments, choruses or songs are used and people sing them and dance together (187).

The position of Daniel Ilega is not totally exclusive to the Christian religion as theatre expresses relationships in other religiouns. The earliest forms of religions employed theatrical elements. In fact, religious rituals are almost impossible without the incorporation of theatrical effects. Drums, chants, choric movements, incantations, songs, costumes are theatrical elements that are present in any form of religious worship. Traditional religion, oriental traditions and the classical traditions inevitably used the theatre to achieve aesthetic and boisterous performances. The rules and flows of traditional religion worship used music, dance, dialogue etc to evoke atmosphere, spectacle and harmony. The discourse on the use of theatrics by religious organizations appears centered on classical traditions and Christians worship. This is because the use of theatrics is not copious in Islam; since Islam abhors any form of imitation. This has affected development in the relationship between the theatre and Islam. Robert Cohen affirms that:

Much of the ancient theatre tradition had disappeared by the third century B.E. and the religion of Islam which originated early in the seventh century A.D. viewed depictions of human in both the visual and performing arts as irreligious (226).

It cannot be totally argued that Islam does not use theatrics entirely. Some effects are evident from a close observation of Islamic worship activities. Recitation, chants and in modern times music and dance have been incorporated into Islamic worship. Richard Schaefer clearly explains the inevitability of theatrics in any form of religion as he notes that:

Religion, whether it be Budhism, Islam, Christianity or Judiasm, offers people meaning and purpose for their lives... although subjective and not fully accepted, these values and ends help a society to function as an integrated social system. For example funerals, weddings, bar and bat mitzvahs and confirmations serve to integrate people...(377).

Religion is more of a response by a people in a particular environment to mitigate challenges and as a means of sustainability in the environment. Most people may be quick to challenge the assumption expressed above, but it is obvious that the challenges posed by the environment that man finds himself induces the means of dealing with it. The most important fact to note is that religion in whatever form uses the culture and the environment to function. Theatre is a culture product and so its use in religious ceremonies is quite apropos. Fatunbi Verger explains that "On catholic feast days, the slaves were allowed to dance and enjoy themselves in their own way to the accompaniment of drums..."(63)

Theatre is a strong index of culture and so when religion and culture come together, the theatre must manifest. The slaves culture exhuded in the catholic worship because the culture component had to be incorporated in the religious activities of the slaves. In all religious activities, it is evident that the use of theatrics drives the process of the rites. In traditional African religion, theatrical effects become almost inevitable.

Edwin Wilson notes that:

In virtually every culture in recorded history or in anthropological studies, we find rituals, religious ceremonies and celebrations that include elements of theatre (5).Traditional theatre involves religions activities. In most cases, the theatre and religious rites are inseparable. The ceremonies and rituals in traditional religion contain several theatrical elements. In fact, recorded history reveals that the theatre evolved from rituals or religious activities.All forms of worship incorporate theatrical elements. It is apropos to state that worship of any kind is incomplete without theatrical activities or elements. Most times, it is impossible to distinguish theatre from worship. In fact, the thesis implicit in this assumption is that the theatre in religious worship adds aesthetics and values. It is tempting to state that the theatre is an additive to religion that spaces religious worship and encourages adherents. The theatrics in religious activities produce several effects which include graphic presentation of the rites and attracting people to worship. The other effects include advertising the activities of worship and creating atmosphere for worship. The appeal in theatrics serves as stimuli that make people respond to religious worship. The music, dance, song, costume and chants are the embellishments that make religious worships boisterous as well create a disarming appeal. These theatrics that combine emotional and physical appeal disarm all resistance or rationality. The early Christian worshippers were drawn to worship through the theatrics involved. The difficulties in bringing the message of Christianity, a strange religion to the people was mediated through the theatrics employed.The theatre as a collaborative art form uses live performance to present the message of Christianity to a live audience. Most times the live performance become developed and is performed separately. 
Alexis Soloski notes that:By all rights, theatre ought to say its prayers. According to most origin stories, theatre emerged out of religious ritual not once but twice. Initially courtesy of the Greeks and then again in medieval Europe, where many scholars traced the rebirth of theatre to the quan quaritis, a shorts section of dialogue in the Easter liturgy (3). The medieval period which sought copious use of theatrics in replaying the church activities increased the collaboration between the church and the theatre. Though scholars have presented religion as the birth place of the theatre but a critical look reveals that the theatre has existed even before religion. A reading of the earlier activities of the early man reveals the evidence of theatre. Whatever is the argument, the theatre remains a vital activity of most religious worship; particularly in Christendom. There are situations where from the early stages of the church, that the church had to developed theatre that ran as commercial enterprise. In Nigeria today, both Pentecostal and Orthodox churches compete on a large scale use of the theatre in worship activities. Most church organizations run separate budgets and prorgammes of the theatre. The essence of the robust use of the theatre in church organization is to enhance popularity and attract patronage. The churches have professional dance groups in addition to choral groups that perform for the church and outside. The church has so domesticated theatre that standup comedy has become a strong feature of church worship. The theatre creates a robust atmosphere for the church to thrive. It is important to note that theatre has enhanced the growth of the church in Nigeria. This accounts for the no expense spared by the churches in the use of the theatre. Professional musicians and drummers have now occupied centre stage in the church. It is observable that rehearsal schedules are almost replacing bible class sessions in the churches in Nigeria. The theatre is expanding daily in the activities of the church to the extent that not only theatrics are used but as a developed programme of the church.

\section{ELEMENTS OF THEATRE IN WORSHIP}

The theatre creates mental pictures and presents graphic images of human experiences. This unique aspect of the theatre serves the collaboration and the employment in the church activities. The performance involves the portrayal of human crisis and experiences that are evidenced on stage for the audience. The audience consists of the people caught in the misery of the industrial society where human values are negotiated and commodified. The Christian message appears abstract to the people and so the only way to reduce the abstraction or bring the church and the people together is to employ elements of the theatre that are already in use by the people to deepen the rapport. Thus it is in this assumption that the theatre aided the breaking of rigidities, sectarian differences and the fourth wall so to speak between the church and the people. Attempts will be made from this section of the paper to analyze the various elements of the theatre used in church worship that have kept the church in the main stream of human activities despite the distraction from other religions and social activities. Some observers are of the opinion that the failure of institutions and governance has increased the viability of the church.

Theatre has found its root in religious and particularly in Christian worship in Nigeria today because it is a new form of evangelism. It is generally believed that the traditional method of preaching both for the adherents and the outsiders is no more attractive. The impulse towards the use of theatre in Christian worship is universal and not limited to Nigeria. The most commonly used elements of the theatre include: dance, songs, costumes, music etc. Dance as a theatrical element in worship employs both ethnic and social dances. Ilami Krama notes that :

Dance which expresses emotion is expressed through time sequence and space patterns ....... There are two forms of dance, the ethnic and social dance (28).The dance found in the church activities is not just simple dance but range from well choreographed dances to ethnic dance. The dance lifts some secular rhythms or tribal identities. Churches use dance steps that reflect the ethnic groups in their locations. It is usual to see Yoruba dance in western Nigeria church sessions. More so, the southern part of Nigeria uses a lot of Awugiri dance in the service, while the eastern part of Nigeria is not left out in the use of ethnic dance elements.Since the theatre has broken rigidities between the church and secular society, it is common to see trendy dances in the church service. It is common to see such dances as Galala, Salsha, Soke, Alanta, Azento or Etigi. The aim here is not to run down the use of dance or dance forms in church service. However, it is vital to note that dance has come to stay in the church sessions and allows a robust rapport between the church and society.Fatunbi Verger explains this collaboration of dance and the general flow of the service programme:On catholic feast days, the slaves were allowed to dance and enjoy themselves in their own way to the accompaniment of drums ... the songs and dances, the real meaning of which escaped the masters were ritual dances brought from Africa and addressed to their gods. (62).The second theatrical element employed in worship is sound which evokes atmosphere. The sound employed includes chants, chorus, songs and music. Ilami Krama explains that:Songs are lyrical and vocal expressions designed for adding meaning to human activities. Songs generate emotion, atmosphere, vanity and specific to the event ..... music is an essential channel through which life expectation and emotions are expressed (24).The sound be it instrumental or vocal sound produces emotional entry for worshippers into the spirit realm. The sound in worship is exaggerated. The songs, chants etc, are raised louder 
than necessary. The chants of Amen, and Hossana as well as other sounds are responses from the members who form the audience. In weddings, christmas and burial ceremonies, the sound may draw deep emotions. The sound as an element of worship may also come inform of prayers. In both the Pentecostal and orthodox forms of worship, prayers are said loud that the sound made draws the worshippers into a form of orgy. The music in worship may range from hand dapping, to vocal rendition of instruments or produced from musical instruments. The music creates atmosphere as well as deepen the emotional wrap of the worshippers that they become obvious of situations. Ritual as an element of the theatre is often abused when seen from uninformed people. The word ritual often connotes fetish or primitives rites. However, the concept of ritual has been expanded to accommodate a vareity of human applications. Ilami Krama infers that:

Rituals are repeated activities that produce desired results, rituals combine too kinds of forces which comprise of rules and flow. (20)In the worship programme one can witness evidence of ritual as the combine elements of rule and flow aid the progress of the service. The service may range from divine service, feasting, service of songs, marriages, burials to naming ceremonies. The service begins with a definite rhythm that signals the commencement and the general flow of the service that remain unbroken. Thus the consummation of the service follows the ritual flow of a definite rule.

Edwin Wilson also expanciates the evidence of ritual in church service as a theatrical event as he notes that; A ritual is the acting out of an established, prescribed procedure and can range from a family event, such as animal thanksgiving or Christmas dinner, or to the elaborate religions ceremonies of a Roman Catholic high mass or a Jewish Yom rippur Service during High Holy Days (6). Ordinarily the word ritual should not be mentioned in Christian worship. However, the various activities involved in worship service connote the process as procedure or rule and flow of the activity. The rule and flow delineate and define the specific activities. The purification of the rite or activity in the church will determine the perception and response of the people. The worshippers attitude is guided by the nature of the rite which to a great extent revolves around the rule and flow that characterize the events. Every event has ritual embedded and so strongly speaking ritual is not restricted to the primitive performances of propitiation. Rituals have acquired wider application as there are secular and sacred rituals. The rituals in the assumption of the paper are those procedures that are followed sequentially and deepen the value of the church processes. A simple naming ceremony has a conditioned flow and the rule must be followed or else it loses appeal and value. Costumes as elements of the theatre used in the church create atmosphere and value. The theatre like the church deals with human concerns and so costumes are outer adornment capable of changing what seems to be stable and enduring. Robert Lystad adds that:The term costumes refers to the style of dress, including additional objects which are worn or carried typical of the mood of celebration(3).Costumes are powerful animators of human actions and so add or enhance the church service processes. The Soutan, cassock, turbans, white garments and surplice worn in church services deepen the character and role of members. The costumes delineate the roles and status of members. The priests are classified by the robes they wear. The choir members wear distinct costumes to enhance their status and performance. Amongst the priests various costumes are worn which further distinguish the priests in their ranks. Costumes have added the sacredness of the church over the centuries of existence. The costumes apart from adding colour and piety also create atmosphere during the processes of church services. It is apropos to maintain that the costumes used in church worship transform into artistic expression and beauty. Another vital element of the theatre prevalent in church worship is the audience. Human beings are very significant and at the center of every church worship. The various elements discussed have created atmosphere for the robust activities in the church worship. The human element is very vital for the final consummation of the rites. The atmosphere and the aesthetics created through the other elements appeal to the members who constitute the audience. The theatrical appeal has been very effective in bringing the church to the society. The effect is felt in the easy flow of members to the church programmes. Crusade worships draw a greater audience which comprises of actual members and those attracted by the theatrics employed. It is usually difficult to know the actual members since everybody attending marriage ceremonies, burial ceremonies and even child naming ceremonies flows with the rite accompanied by the aesthetics embellished in the theatrics. It is important to note that the audience in Christian worship is as variegated as in traditional worship. The audience is categorized into both human and spirit audience. The human audience can be visible but the spirit audience in the form of angels and the heavenly hosts form the spirit audience that are accorded presence as well as reverence. The spirit audience and the human audience both enjoy the theatrical appeals. Without the theatrical elements the church programmes would have been uninteresting being the reason for the early apathy. The element of possession is discussed in hushed tones as the idea is not openly accepted in Christian doctrines. Spirit possession is an essential aspect of worship both in traditional and Christian worship. There is a tiny line linking spirit possession and theatrical character transformation. The idea of character transformation is preferably accepted than spirit possession. Whatever form that is applied, there is evidence of possession where in the course of service either the priest enters into a spirit realm and the audience is aware of the transformation. When also the priests returns into the physical character, the audience knows the difference. The transformation of character or spirit possession is not 
experienced by the priest alone. The worships in the course of prayers or singing sessions can go into possession where prophesies manifests or speaking in tones. In some extreme cases, the character possessed or transformed may fall and roll on the ground as well as become unconscious for a period. Both the loss of consciousness and loud shouting are serious manifestations of spirit possessions that are accepted as aspects of worship. Spirit possession is a strong element of traditional theatre and so is also evident in modern Christian worship. The nature of Christian doctrines may not have allowed the exploration of the element of spirit possession. However, no matter the extent of denial, there exists spirit possession as a strong element of theatre used in Christian worship.

Lighting is one of the elements that cannot escape being discussed in this paper. Light both in theatrical performances and in Christian worship has expanded beyond providing visibility. Lighting has deepened the rites of Christian worship. In the early period of Christian worship candle light provided the visibility and aesthetics of worship. The worship would have been incomplete with the colour added from the various colours of candle light. The candles light were and in most cases still a vital aspect or element of the worship activity. In modern or to be specific in the Pentecostal forms of worship, lighting has become an essential element that animates the various activities. Exhortic lighting programmes are provided in worship programmes. The pulpit and alters have specific lighting designs. Some rites as Christmas have spectacular lighting designs to appeal to the emotions of the season.

\section{CONCLUSION}

The focus of this paper has been to establish the symmetrical or collaborative relationship between theatre and the church. Both the church and theatre are human institutions that are expressive of human actions as well as feelings. While the theatre is subtle in the appeal, the church is more coercive and compelling. However, both the church and theatre deal with humans emotions as well as use common effects to achieve this. The element of acting may not be so defined in Christian worship but is applied and so the various elements that edify actions in the theatre are applied in the church worship. Nigeria is a transiting society from indigenous cultures to popular culture and so also all the institutions are transiting. The evidence of indigenous or traditional theatre elements prevalent in modern church worship can be adduced from the transiting processes. The examination of theatrical elements in Christian worship is not intended to degrade but to encourage a robust application of the theatre to expand the drive for evangelism and the acceptance of Christianity by the society. The church is where everybody is heading to particularly with the collapse of the political and social institutions. The present collapse of the Nigerian economy has driven most people to the church in search of pleasure and salvation, therefore the use of theatrical elements to enhance rapport is apropos.

\section{Works Cited}

[1] Alexis Soloski; 'The Theatre should say its prayers', in the guardian https:www.theguardian.courstretrieved on $25^{\text {th }}$ January 2017:10

[2] Daniel Ilega; (ed) Studies in World Religion, Ado-Ekiti, Hamaz Global Publishers. 2001

[3] Fatunbe Verger;' The Status of Yoruba Religion in Brazil' in Kiabara Journal Port Harcourt, University of Port Harcourt Press, 1978.

[4] Edwin Wilson, the theatre experience (7t edition), new York, Mcgraw Hill, 2004

[5] Ilami Krama, African Traditional Theatre and Drama: Themes and perspectives. Port Harcourt University of Port Harcourt, Press. 2013

[6] Robert Cohen, Theatre, brief edition new York, McGraw Hill 2006

[7] Robert Lystad. 'Celebration: A World of Art and Ritual' In Africa in Print Washington, D.C. Smithson Institution Press, 1982

[8] Richard Schaefer, Sociology (Seventh Edition) New York, McGraw Hill 2001. 